\title{
Evaluation of the performance of a chlorhexidine gel containing CVC dressing in a clinical environment
}

\author{
T Karpanen ${ }^{1 *}$, A Casey ${ }^{1}$, T Whitehouse ${ }^{2}$, P Nightingale ${ }^{3}$, I Das $^{1}$, TS Elliott ${ }^{4}$ \\ From 3rd International Conference on Prevention and Infection Control (ICPIC 2015) \\ Geneva, Switzerland. 16-19 June 2015
}

\begin{abstract}
Introduction
Although infection risk associated with central venous catheters $(\mathrm{CVC})$ has reduced in recent years, the use of $\mathrm{CVC}$ are still associated with relatively large number of infections, leading to increased patient morbidity and healthcare costs. A major source of microbial colonisation and infection of short term CVC is the patients' endogenous skin microorganisms located at the catheter insertion site.
\end{abstract}

\section{Objectives}

To evaluate the introduction and performance of a chlorhexidine (CHG) gel CVC dressing in a critical care environment.

\section{Methods}

Following Ethical committee and Trust approvals and staff training, a transparent film-dressing incorporating an aqueous CHG gel was introduced to critical care patients over a 9 month period. Skin reactions to the dressings and performance characteristics of the dressings were monitored. Any adverse events were determined as per standard clinical practice. Healthcare workers' perceptions of the performance of the dressing were evaluated at the end of the study period.

\section{Results}

There were no reports of severe contact dermatitis associated with the $\mathrm{CHG}$ or standard dressings. Close assessment of skin condition at the CVC site was evaluated in 273 patients who had given their consent. Following dressing removal, mild redness under the adhesive was

${ }^{1}$ Clinical Microbiology, University Hospitals Birmingham NHS Foundation Trust, UK

Full list of author information is available at the end of the article reported in one standard dressing group patient $(0.7 \%$, $\mathrm{n}=137)$ and in seven CHG dressing group patients $(5.1 \%$, $\mathrm{n}=136$ ). Only one patient presented with mild redness under the CHG gel part of the dressing $(0.7 \%, \mathrm{n}=136)$. All the above symptoms resolved within $24 \mathrm{~h}$ following dressing removal.

A questionnaire was distributed to critical care nursing staff and clinicians in theatres, who had experience handling and observing both the standard CVC (Tegaderm IV dressing) and CHG gel containing CVC dressing (CHG Tegaderm). In total, 71 nurses and 10 clinicians responded to the survey. Staff was satisfied with the performance of the CHG dressing, with $97.5 \%$ of the respondents rating the overall performance of the CHG gel dressing as: the same as (11.1\%), better (35.8\%) or much better $(50.6 \%)$ than the standard CVC dressing.

\section{Conclusion}

The CHG gel CVC dressing was well tolerated by patients and performed effectively in the critical care environment.

\section{Disclosure of interest}

T. Karpanen Grant/Research support from: received funding for attending the ICPIC (2015) conference, A. Casey: None declared, T. Whitehouse: None declared, P. Nightingale: None declared, I. Das: None declared, T. Elliott Speaker's bureau of: received honoraria for presentations at symposia, Consultant for: has received honoraria for attendance at advisory board meetings.

\section{Authors' details}

${ }^{1}$ Clinical Microbiology, University Hospitals Birmingham NHS Foundation Trust, UK. ${ }^{2}$ Department of Anaesthetics and Intensive Care, University Hospitals Birmingham NHS Foundation Trust, UK. ${ }^{3}$ Wolfson Computer
() Biomed Central

(c) 2015 Karpanen et al; licensee BioMed Central Ltd. This is an Open Access article distributed under the terms of the Creative Commons Attribution License (http://creativecommons.org/licenses/by/4.0), which permits unrestricted use, distribution, and reproduction in any medium, provided the original work is properly cited. The Creative Commons Public Domain Dedication waiver (http://creativecommons.org/publicdomain/zero/1.0/) applies to the data made available in this article, unless otherwise stated. 
Laboratory, University Hospitals Birmingham NHS Foundation Trust, UK.

${ }^{4}$ Corporate Division, University Hospitals Birmingham NHS Foundation Trust, UK.

Published: 16 June 2015

doi:10.1186/2047-2994-4-S1-I1

Cite this article as: Karpanen et al.: Evaluation of the performance of a chlorhexidine gel containing CVC dressing in a clinical environment.

Antimicrobial Resistance and Infection Control 2015 4(Suppl 1):11.

Submit your next manuscript to BioMed Central and take full advantage of:

- Convenient online submission

- Thorough peer review

- No space constraints or color figure charges

- Immediate publication on acceptance

- Inclusion in PubMed, CAS, Scopus and Google Scholar

- Research which is freely available for redistribution

Submit your manuscript at www.biomedcentral.com/submit
O) BioMed Central 